\title{
Fra Grundtvig-litteraturen
}

\section{Vartovbogen 1998}

\author{
Af William Michelsen
}

$O$, dejlige land. Kirkeligt Samfund i 100 år 1898-1998.

Vartovbogen 1998. Redaktion Preben Sørensen. Pris 125.

Kirkeligt Samfunds Forlag, Vartov, Farvergade 27, 1463 Kфbenhavn K.

Det er en meget smuk bog, der her udgives af Kirkeligt Samfund. Indtrykket skyldes ikke mindst omslaget og de $10 \emptyset$ vrige farvebilleder i akryl på papir af kunstneren Kirsten Dissing Overgaard, der ikke har givet sine billeder nogen titler. Bagsiden oplyser imidlertid udtrykkeligt: »Redaktion, billedtekster og lay out: Preben Sørensen, Aabenraa. "Det må altså være ham, der har ansvaret for den overtitel, bogen har fået, begyndelseslinien til det centrale digt af Grundtvig, »De Levendes Land«, som han i 1832 udgav i L.C. Hagens »Historiske Psalmer og Riim til Børne-Lærdom«. Hvis nogen skulle have fået den forestilling, at det dejlige land, billedet gengiver, er det samme som det, Grundtvigs digt handler om, er det altså ikke kunstnerens skyld. Det dejlige land, Grundtvig taler om i sit digt, er jo ikke Danmark i forsommeren, men det evige liv. Men i digterens forestillingsverden ligner synet af Guds rige eller det evige liv i den grad billedet af Danmark i forsommeren, art man kan fristes til at forveksle dem. Det er måske også billederne, der har gjort bogen $25 \mathrm{kr}$. dyrere end sædvanligt; men det tager man gerne med, især fordi formandens forord til bogen og de enkelte bidrag til den opfordrer til den kritiske læsning, som er bogens hensigt, og som gør den værdifuld.

Det ser ud til, at redaktøren har bedt bestemte bidragydere besvare ganske bestemte, af ham formulerede spørgsmål. Kirkeligt Samfunds næstformand, Inge Lise Pedersen, har ligefrem indledt sin artikel med ordene: »Undertitlen var den arbejdstitel, jeg fik...« Hendes egen overtitel er »For sammenhængens skyld «, men den forstår man jo først, når man har læst artiklen. Undertiden lyder: „Om lægfolkets rolle i det kirkelige landskab«, og dét er netop problemet. Udlændinge har svært ved at forstå, hvilket forhold almindelige mennesker i Danmark har til kirken, og det er måske endnu sværere for os danske at forklare dem det. Hele tre artikler har ganske tilsvarende undertitler: Niels Henrik Arendts artikel »Om gudstjenesten i Den danske Folkekirke«, Johs. Nørregaard Frandsens om »Det folkeliges fysiognomi i en international tidsalder «. Den sidste er nok den mest spændende, fordi den ganske konkret beskriver, hvordan Højlund selv er vokset op i et pietistisk hjem, men mødte det folkelige på Askov, som om han var komme »hjem til det grundtvigske.«(Citationstegnene er sat af ham selv.) Han forestiller sig, at man i fremtiden også som europæer kan være folkelig. Hvortil jeg vil føje, at dét var Grundtvig. Han var født i tvillingriget og helstaten, men tog bevidst afstand fra den tyske idealisme og nationalisme. Hans begreb om folkelighed hang sammen med hans begreb om menneskelivet. Når Højlund kalder sin artikel »Den vigende horisont «, har jeg svært ved at følge ham. Jeg synes godt man kan være dansk europæer. Det var Grundtvig. Han behøvede ikke at blive »omvendt « i den henseende.

I sit forord minder Kirkeligt Samfunds formand, provst Jens Ole Henriksen om det skarpe angreb, der blev rettet mod stiftelsen af Kirkeligt Samfund af frimenighedspræst Valdemar Brücker for 100 år siden: »At ville gå den kristne menighed i bedene og 
organisere på dåbspagtens grund «kaldte Brücker en »åndsfornyelse«. Det har imidlertid aldrig været hverken Grundtvigs eller hans venners og efterfølgeres hensigt at danne nogen organisation, der kunne eller ville træde i den kristne menigheds sted. Men det fremgår af dén kirkelige situation, hvori Kirkeligt Samfund stiftedes, og som er beskrevet i indledningen til Frands Ole Overgaards »historiske rids « af de 100 år, der er gået, at det var nødvendigt med et grundtvigsk svar såvel på stiftelsen af Indre Mission som på den liberale teologi, og den nuværende formand erklærer det i sit forord for »Kirkeligt Samfunds hovedanliggende at gøre hvad vi kan, for at folkekirken kan forblive noget så uorganiseret, ubestemmeligt og uoverskueligt som det danske folks kirke.« Det er disse bestræbelser, hele bogen handler om.

Efter det historiske rids på 45 sider følger Kim Arne Pedersens kun 14 sider lange redeg $\emptyset$ relse for hans studier over spørgsmålet: »Hvad betyder det grundtvigske i dag?« Det gælder om denne artikel som om hele bogen, at den kan ikke refereres. Man bliver nødt til at læse den, hvis man vil vide, ikke blot hvad det grundtvigske betyder i dag, men overhovedet hvad forholdet er mellem folk og kirke i Danmark i dag. Den korteste og klareste fremstilling er formentlig Niels Thomsens elleve punkter med overskriften »Folk, kirke og kirkelighed « til forsvar for kærnesætningerne i det første punkt: »Hvor kirkeligheden får magt, er det forbi med den fri vekselvirkning mellem kirke og folk. Kirkelighed vil tage magt over folket, og ikke nok med det. Kirkeligheden vil også tage magten over evangeliet, så ikke blot folkets, men også evangeliets frihed er i fare, hvor kirkeligheden svulmer op.«

Finn Jacobis artikel »Skole og kristendom«bygger ikke blot på hans erfaring som religionslærer i gymnasiet, men også på erindringer fra folkeskolen. Han citerer direkte kirkeminister Bodil Kochs ord på et møde, han overværede i 1953, om folkeskolens religionsundervisning: $\gg 80 \%$ af denne undervisning er mere nedbrydende end opbyggende. «Da han selv begyndte sin undervisning i gymnasiet, måtte han give hende ret. »Jeg stod over for en barriere af modvilje mod at blive undervist i religion, skabt af folkeskolens konfessionelle religionsundervisning... «At Bodil Kochs ord fremkaldte en ny holdning hos religionslærerne i folkeskolen, bl.a. ved oprettelsen af en ny materialecentral, indført af Kaj Vardrup, og et samarbejde mellem folkeskole- og gymnasielærere i religion, kan jeg kun tilføje ved hjælp af en folkeskolelærers erindringer.

Den værdifuldeste artikel om eftervirkningerne af Grundtvigs tanker om en folkelig højskole er i denne bog Frederik Christensens artikel "Den grundtvigske familie«, bygget over hans egne erfaringer og hans fortælling om Ernst Triers i Vallekilde. Han slutter sin artikel med et overraskende forslag til løsning af folkehøjskolernes krise i dag: »I virkeligheden er de magter, der truer vort folkestyre og højskolen, stort set de samme. Derfor kan vi være kommet til den periode da politikerne og højskolen bør indgå en kontrakt. I den skal højskolen forpligtes til som undervisningsfundament at have etik/ filosofi og historie/samfundsforståelse på skemaet. Har man ikke det, er man ikke højskole. Som betaling må politikerne indføre »filosofikum« på højskolen som forudsætning for at kunne tage en videregående uddannelse. Problemet er jo, at de fællesmenneskelige anliggender stort set er forsvundet fra universiteter og læreanstalter, og den næste generation er dårligt rustet til at varetage et samfund, hvor netop disse anliggender turde få større og større betydning. Derfor står politikerne mere og mere alene, når de skal finde udveje for fællesskabets fremtid. Den opgave burde ikke være fremmed for højskolen. «Det er en forhenværende rektor for Nordens folkelige akademi 